\title{
The Effect of Governance on FDI Inflows in ASEAN
}

\author{
Ranynda Niarachma1,a*; Nury Effendi ${ }^{2, a}$; Eva Ervani ${ }^{3, a}$ \\ 1 ranynda19001@mail.unpad.ac.id; ${ }^{2}$ nury.effendi@unpad.ac.id; ${ }^{3}$ eva.ervani@unpad.ac.id \\ a Master Program in Applied Economics, Universitas Padjadjaran \\ * corresponding author
}

\section{ARTICLE INFO}

Article history

Received 2021-02-03

Revised 2021-03-30

Accepted 2021-04-01

Keywords

ASEAN

Foreign Direct Investment

Institutional Quality

Good Governance

Panel Data

\section{ABSTRACT}

This study examines the effect of governance on FDI inflows in ASEAN countries for the period 2002-2018 using the Worldwide Governance Indicator (WGI) index. This study uses a principal component analysis (PCA) method to reduce six WGI indexes and performs panel data regression analysis using fixed-effect GLS (cross-section weights). This study uses data from World Bank for FDI, WGI, and several control variables. The results of this study have provided empirical evidence that good governance is a very important key factor in encouraging FDI inflows to host countries. This study finds three governance elements that have a positive relationship with FDI inflows in ASEAN countries are the quality of regulations, rule of law, and control of corruption.

This is an open-access article under the CC-BY-SA license.

\section{Introduction}

The world economy has entered a new era in line with globalization. The openness of the world of trade and investment has provided opportunities for multinational companies around the world to be able to regulate their production activities beyond national borders (UNCTAD, 2003). The existence of private capital flows in the form of Foreign Direct Investment (FDI) is one of the characteristics of international economic openness which is one of the important sources of funding for development that contributes to productivity advancement (Sahoo et al., 2014). This is because for most countries FDI is a source of employment, increased business competition, and transfer of technology and skills obtained from home countries (Borensztein et al., 1998; Cambazoglu \& Karaalp, 2014; Iamsiraroj, 2016; Xaypanya et al., 2015).

The various benefits of FDI make FDI one of the important things for the economies of countries in Asia, including countries that are members of the Association of Southeast Asian Nations (ASEAN). ASEAN is a region with a population of 660 million people with the achievement of Gross Domestic Product (GDP) reaching USD 3.17 trillion in 2019. ASEAN 
recorded the highest FDI inflows in 2019, which increased by 3.75\% from USD 153 billion in 2018 to USD 158.8 billion in 2019 (ACSS, 2020). The increase in investment entering the ASEAN region reflects increasing global attention to the Southeast Asian region.

Table 1. The Most Inhibiting Factors of Doing Business in the World

\begin{tabular}{lclc}
\hline \multicolumn{4}{c}{ Advanced Economies } \\
\hline \multicolumn{1}{c}{$\mathbf{2 0 0 7}$} & \multicolumn{1}{c}{$\mathbf{2 0 1 5}$} \\
\hline \multicolumn{1}{c}{ Factors } & Skor & \multicolumn{1}{c}{ Factors } & Skor \\
\hline Government bureaucracy & 13.6 & Government bureaucracy & 14.2 \\
Restrictive labor regulations & 13.6 & Tax rates & 13.1 \\
Tax rates & 11.9 & Restrictive labor regulations & 12.8 \\
Complexity of tax regulations & 10.7 & Access to finance & 10.8 \\
Inadequately educated workforce & 9.0 & Complexity of tax regulations & 8.8 \\
\hline
\end{tabular}

Emerging Market and Developed Economies

2007

2015

\begin{tabular}{lclc}
\hline \multicolumn{1}{c}{ Factors } & Skor & \multicolumn{1}{c}{ Factors } & Skor \\
\hline Government bureaucracy & 12.3 & Access to finance & 11.7 \\
Corruption & 11.4 & Corruption & 11.4 \\
Access to finance & 9.8 & Government bureaucracy & 11.3 \\
\hline
\end{tabular}

Source: World Economic Forum (2015)

Various factors influence the flow of FDI between countries, the diversity of these factors makes attracting FDI difficult for most countries (Bannaga et al, 2013). Several previous studies have placed economic factors as the main determinants that can attract FDI inflows to a country. However, based on the results of the Executive Opinion Survey analysis conducted by the World Economic Forum (2015) in Table 1, it is revealed that factors related to governance are a major problem in most economies. Government bureaucracy is still a constraining factor in doing business in developed countries and remains one of the three most pressing problems in developing countries. Meanwhile, corruption, which also affects the quality of government, is in second place. Also, the results of the World Investment Prospect Survey 2014-2016 published by UNCTAD (2014) underline that the uncertainty of government policies and geopolitical risks are other factors of governance that affect the entry of FDI in a country.

Most of the literature has examined the eclectic theory of the location advantages approach because the variables can be observed. Whereas the traditional approach in determining the factors that influence FDI flows emphasizes the measurement of marketseeking and resource-seeking motives such as market size (Alam \& Shah, 2013; Xaypanya et al., 2015), labor costs (Blaise, 2005; Voyer \& Beamish, 2004), level of openness (Alam \& Shah, 2013; Asiedu, 2002; Xaypanya et al., 2015), and macroeconomic stability (Kahouli \& 
Maktouf, 2015). Research in the last few years has put forward another opinion which states that the quality of governance / institutional quality plays an important role in explaining the determinants of FDI from the side of efficiency-seeking motive (Bellos \& Subasat, 2012; Buchanan et al, 2012; Ullah \& Khan, 2017).

There are various types of measurements and data sources in measuring the quality of a country's governance / institutional quality, Bannaga et al., (2013); Buchanan et al., (2012); Kayalvizhi \& Thenmozhi, (2017); Mengistu \& Adhikary, (2011) used the sixdimensional index of the World Governance Indicators (WGI) proposed by Kaufmann et al. (2011), namely political stability and absence of violence/terrorism, voice and accountability, regulatory quality, rule of law, government effectiveness, and control of corruption. Several previous studies conducted by Bannaga et al., 2013; Kayalvizhi \& Thenmozhi, 2018; and Mengistu \& Adhikary, 2011 have tried to examine the six dimensions of the World Governance Indicators (WGI) proposed by Kaufmann et al., (2011) on FDI. The results of these studies show varied results, namely several indicators of governance / institutional quality significantly influence FDI, namely political stability (Bannaga et al., 2013; Mengistu \& Adhikary, 2011), voice and accountability, regulatory quality (Bannaga et al., 2013). al., 2013), government effectiveness stability (Bannaga et al., 2013; Mengistu \& Adhikary, 2011), rule of law, and control of corruption (Mengistu \& Adhikary, 2011).

The relationship between governance factors and the entry of FDI can be explained by referring to the cost-effectiveness of investing. When a government can create conditions of stable governance, it will make market conditions predictable and reliable. This is a form of certainty that can be provided by the government to investors and companies so that they can maximize all available resources in the host country to increase efficiency and reduce production costs (Cuervo-cazurra, 2008; Jensen, 2003 ). According to Mengistu \& Adhikary (2011) transparency, accountability, and law enforcement are important parts of governance that will motivate investors to channel their capital to a country. No investor is interested in investing in a country that has a complicated bureaucracy and has loopholes of corruption because it is thought to increase transaction costs in investing. It can be concluded that the quality of good governance in a country can help create a conducive business and investment climate to promote economic growth. On the other hand, a country with a low-quality governance infrastructure will make investors reluctant to invest as a result of the uncertainty it creates (Globerman \& Sapiro, 2002). This shows that the quality of governance/governance infrastructure in a country is one of the determining factors for the inflow of FDI. Therefore this study focuses on analyzing the relationship between governance infrastructure and FDI inflows. 
To analyze the effect of governance on FDI inflows, this study uses a set of governance variables developed and updated by Kaufmann et al. (2011), because of how many previous studies it can be concluded that governance/governance indicators are the most commonly used and have broad country coverage. Kaufmann broadly defines governance as a tradition and institutions/institutions that have authority in a country including (1) the process of a government being elected, supervised until replaced, (2) the ability of the government to selectively formulate and implement sound policies, and (3) there is a sense of respect for the state and citizens for the existence of institutions/institutions that regulate various interactions in society. Under this concept, six aggregate indicators have been developed that measure subjective perceptions of the quality of government in various countries by taking data from two types of sources, namely cross-country population surveys, and expert opinion polls. These indicators are published by the World Bank as Worldwide Governance Indicators (WGI). Each indicator represents a different aspect of governance, namely: voice and accountability, political stability and absence of violence/terrorism, government effectiveness, regulatory quality, rule of law, and control of corruption.

\section{Research Methods}

This study uses panel data regression analysis with the type of data used as secondary data from ten ASEAN countries in the period 2002-2018. The data sources for this research come from the Worldwide Governance Indicators (WGI) and the World Development Indicators (WDI) published by the World Bank. To analyze the effect of governance on FDI inflows in ASEAN countries, the FDI variable is used as the dependent variable and seven explanatory variables, namely the governance index (GOVN), voice and accountability (VOA), political stability, and absence of variables. violence/terrorism (PSAB), government effectiveness (GOVE), regulatory quality (RQ), rule of law (ROL), and control of corruption (COC). Apart from these variables related to governance, FDI flows are also influenced by other determinants related to markets and efficiency. This study uses other determinants related to market and efficiency as control variables, namely market size, domestic investment level, interest rate, gross domestic product (GDP) growth rate, availability of labor, and natural resources in FDI destination countries. The basic form of the regression equation used is as follows:

$\ln ($ FDIit $)=\alpha i+\psi 1$ Institutionsit $+\beta C$ Vit $+\varepsilon i t$

with $\ln \left(\mathrm{FDI}_{\mathrm{it}}\right)$ is the natural logarithm of country i's FDI inflows in year $\mathrm{t}$ (USD); Institutionsit is a governance index that is included in seven different equations, namely an

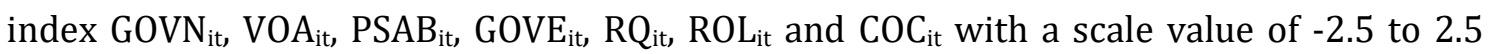


country $\mathrm{i}$ in year $\mathrm{t}$ (Influential hypothesis + ); and $\mathrm{CV}_{\text {it }}$ is a group of control variables, namely $\ln \left(\right.$ MSIZE $\left._{i t}\right)$ the value of the natural logarithm of real GDP for country i in year $t$; DOMINV is ratio of fixed capital formation to GDP (\%) of country i in year t; RATE $\mathrm{it}_{\mathrm{it}}$ is commercial bank lending rates $(\%)$ country $i$ in year $t$; $\ln \left(\mathrm{POP}_{\mathrm{it}}\right)$ is the value of the natural logarithm of the total population of country $i$ in year $t$; GROWTH $H_{\text {it is }}$ GDP growth (\%) of country $i$ in year $t$; and NATEND $D_{\text {it }}$ is ratio of arable land to the total land area (\%) of country $\mathrm{i}$ in year $\mathrm{t}$; $\alpha$ is intercept; $\psi$ is the parameter of each governance indicator; $\beta$ is the coefficient of the control variable; and $i, t, \varepsilon$ is country $i$, in the year of $t$, and error / deviation. So that the final seven equations used in this study are:

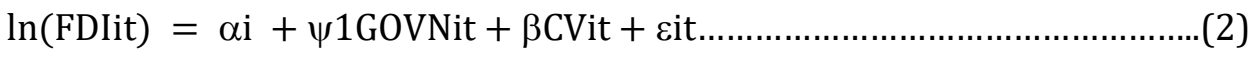

$$
\begin{aligned}
& \ln (\text { FDIit })=\alpha \mathrm{i}+\psi 1 \text { VOAit }+\beta \mathrm{CVit}+\text { eit........................................... (3) }
\end{aligned}
$$

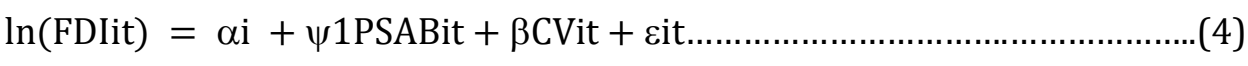

$$
\begin{aligned}
& \ln (\text { FDIit })=\alpha i+\psi 1 \text { GOVEit }+\beta \text { CVit }+ \text { eit ............................................(5) }
\end{aligned}
$$

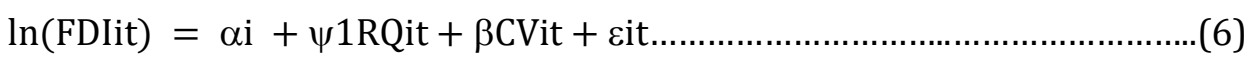

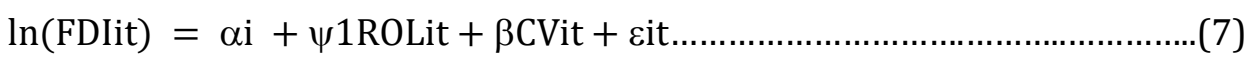

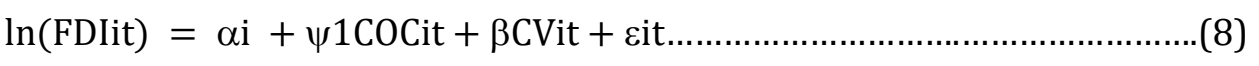

This is done because based on the results of several previous studies it was found that the six WGI governance indexes are highly correlated with one another (Buchanan et al., 2012; Daude \& Stein, 2007; Globerman \& Sapiro, 2002). The existence of correlation will cause multicollinearity problems which make it very difficult to use the entire index into one regression equation. To overcome the multicollinearity problem, this study conducted a factor analysis with the Principal Component Analysis (PCA) procedure, namely extracting the first principal component from the six VOA, PSAB, GOVE, RQ, ROL, and COC indices to obtain one governance index variable (GOVN).

Furthermore, three approaches can be used to estimate panel data, namely, Pooled Least Squares (PLS), Fixed Effect Model (FEM), and Random Effect Model (REM). The PLS approach assumes that behavior between individuals is the same over time. In other words, the intercept and slope are the same for each individual. Meanwhile, the FEM and REM approaches consider the diversity of individuals. In FEM the intercept of the model varies by individual and sample. Meanwhile, REM assumes that the effect of each individual is a random factor. The selection of the best approach is based on a series of formal tests, namely the Chow Test, the Hausman Test, and the Lagrange Multiplier Test.

Classical assumption testing on panel data is based on the estimator used. If the estimator used is Ordinary Least Squares (OLS), then several statistical tests to evaluate the 
model include normality, multicollinearity, heteroscedasticity, and autocorrelation tests. This study uses the estimator Generalized Least Squares (GLS) Cross-section weights. The GLS estimator is an equation that is not biased and consistent but still not BLUE as it meets the OLS basis. The assumptions used in the GLS estimator are the heterogeneity conditions between equations and pay attention to the structure of the different residues between equations (each equation is assumed to be homoscedastic) (Ekananda, 2016).

\section{Result and Discussion}

Based on data from the ASEAN Community Statistical System (ACSS), the condition of FDI in ASEAN has an increasing trend, FDI inflows reached an all-time high in 2019, amounting to USD 158.8 billion. In the ASEAN region, Singapore is the largest FDI recipient country with total FDI inflows during 2015-2019 reaching USD 383.9 billion. Overall, the condition of FDI in the ASEAN region itself shows a fairly unequal trend between Singapore, which is a developed country, and other ASEAN member countries, which are developing countries.

One of the efforts to increase investment growth is by creating a conducive investment climate through the implementation of good governance. An overview of the quality of governance in each ASEAN member country can be seen from the estimated value of the six Worldwide Governance Indicators (WGI) indicators. Voice and accountability include perceptions related to the political process, civil liberties, freedom of expression, freedom of association, and also the political rights of citizens. Political stability and the absence of violence/terrorism describe the perception regarding the possibility of destabilization of government through unconstitutional means or political violence. Government effectiveness describes perceptions about the quality of public services including the quality of government employees, independence from political pressure, and the quality of policy formulation, implementation, and commitment. Regulatory quality describes the perception of the extent to which the government is capable of formulating and implementing various policies and laws and regulations. Rule of law describes the perception of the extent to which agents/officials trust and obey the rules of society, especially regarding the quality of law enforcement in a country. Control of corruption describes the perception of the extent to which public power is used for personal gain or interest. The six indexes have a data range with the lowest scale from -2.5 to the highest 2.5 . 
Table 2. Average Score of WGI ASEAN Countries 2014-2018 Indicators

\begin{tabular}{|c|c|c|c|c|c|c|c|}
\hline \multirow{2}{*}{ Countries } & \multicolumn{6}{|c|}{ Average in 2014-2018 } & \multirow{2}{*}{ Average } \\
\hline & VOA & PSAB & GOVE & $\mathbf{R Q}$ & ROL & $\mathrm{COC}$ & \\
\hline Cambodia & -1.14 & 0.10 & -0.66 & -0.48 & -1.03 & -1.23 & -0.74 \\
\hline $\begin{array}{l}\text { Brunei } \\
\text { Darussalam }\end{array}$ & -0.81 & 1.21 & 1.13 & 0.77 & 0.54 & 0.64 & 0.58 \\
\hline Indonesia & 0.16 & -0.49 & -0.01 & -0.14 & -0.35 & -0.38 & -0.20 \\
\hline Myanmar & -1.02 & -1.08 & -1.12 & -1.01 & -1.06 & -0.70 & -1.00 \\
\hline Malaysia & -0.33 & 0.21 & 0.97 & 0.74 & 0.53 & 0.22 & 0.39 \\
\hline Thailand & -0.98 & -0.89 & 0.35 & 0.19 & -0.06 & -0.42 & -0.30 \\
\hline Philippines & 0.12 & -1.04 & 0.06 & -0.02 & -0.38 & -0.48 & -0.29 \\
\hline Singapore & -0.13 & 1.42 & 2.22 & 2.18 & 1.83 & 2.11 & 1.60 \\
\hline Lao PDR & -1.75 & 0.48 & -0.48 & -0.78 & -0.81 & -0.93 & -0.71 \\
\hline Vietnam & -1.39 & 0.14 & 0.00 & -0.45 & -0.11 & -0.48 & -0.38 \\
\hline
\end{tabular}

Source: WGI, processed

The average index from 2014-2018 shows that Singapore relatively has the best PSAB, GOVE, RQ, ROL, and COC indicator values with an overall average index of 1.60. This is because Singapore is included in the category of developed countries so that it has the quality of governance that is more efficient and effective to support its economy. This is followed by Brunei Darussalam and Malaysia with the overall average index scores of 0.58 and 0.39. Meanwhile, Indonesia has an overall average index value of -0.20 with the highest value on the average VOA index of 0.16. Meanwhile, the other six ASEAN countries have a negative average score for the overall index.

Before estimating panel data, first, a factor analysis (PCA procedure) is carried out to reduce the six VOA, PSAB, GOVE, RQ, ROL, and COC indices so that one new variable is obtained, namely the governance index variable (GOVN). In concluding whether or not a factor analysis is appropriate, it can be seen from the results of the Kaiser-Meyer-Olkin (KMO) statistical test of adequacy and Bartlett's Test of Sphericity. Based on the test results obtained KMO value is 0.813 , it can be concluded that the factor analysis is feasible. In this study, the six governance indicators will be extracted into one factor with the largest eigenvalues criterion, namely 4.717 with the cumulative number of factors formed of 78.614. This shows that one factor that is formed can explain $78.614 \%$ of all governance variables. The value of $78.614 \%$ is considered sufficient to describe the GOVN variable because it has met the requirements of more than $75 \%$.

Furthermore, to determine the best model structure to be used, it is determined based on statistical testing. Based on the Chow test results, the cross-section chi-square p-value of 
the seven models is 0.0000 which is smaller than $0=5 \%$ so that the FEM model is preferred over PLS. LM test is performed to determine the selection of panel data estimation model between REM or PLS. Based on the LM test results, the Breusch-Pagan p-value for the seven models is $0.0000<0=5 \%$ so that it can be concluded that the selected REM model is selected. Then the Hausman test was performed to determine whether REM was preferred over FEM. Based on the results of the Hausman test, it was found that the random crosssection value of the seven models had a probability smaller than $0=5 \%$, the estimation model chosen was FEM for the seven models.

After getting the best model, then a series of classic assumption tests are carried out to find out whether the regression estimation model can produce the Best Linear Un] Estimator (BLUE) estimator. However, in panel data, it involves a variety of times and observations so that it is difficult to maintain homoscedastic conditions in one intact equation. The assumption of homoscedastic and serially uncorrelated error terms cannot be applied because the panel data consisting of several individuals for several periods brings new problems to the error terms. Therefore, to estimate the model in this study is to use the generalized least squares (GLS) estimator which takes into account the diversity of data. The classic assumption test cannot be applied to the GLS estimator because this estimation method is structured to use the information on the uniformity of data from each group or time (Ekananda, 2016). Then the best model used is the FEM model with the GLS estimator cross-section weights.

Table 3 shows the estimation results of the GLS fixed effect regression cross-section weights for the I-IV model. Model I is a regression equation that includes the governance variable from the factor analysis, namely governance (GOVN) and the control variables. Meanwhile, the II-IV models each regress one of the governance variables, namely voice and accountability (VOA), political stability and absence of violence/terrorism (PSAB), and government effectiveness (GOVE) together with the control variables. The estimation results of the governance variable (GOVN) in table 3 indicate that this variable has a positive and significant effect on FDI inflows. This means that the higher the value of governance, the more it will attract more FDI inflows. This result is in line with the research of Buchanan et al. (2012), Globerman \& Sapiro (2002), and Ullah \& Khan (2017) who confirm that good governance infrastructure is an important determinant of FDI inflows because it is often considered to be able to minimize transaction costs, increase the long-term commitment of investors, and provide a description of the condition of political stability, law enforcement and the quality of laws and regulations. 
Table 3. Estimation Result of Regression Models I-IV

\begin{tabular}{|c|c|c|c|c|}
\hline \multirow{2}{*}{$\begin{array}{l}\text { Independent } \\
\text { Variables }\end{array}$} & Model I & Model II & Model III & Model IV \\
\hline & FGLS & FGLS & FGLS & FGLS \\
\hline GOVN & $\begin{array}{c}0.4549 \\
(0.2150)^{* *}\end{array}$ & & & \\
\hline VOA & & $\begin{array}{c}0.1765 \\
(0.1383)\end{array}$ & & \\
\hline PSAB & & & $\begin{array}{c}0.0181 \\
(0.1158)\end{array}$ & \\
\hline GOVE & & & & $\begin{array}{c}0.2917 \\
(0.1880)\end{array}$ \\
\hline DOMINV & $\begin{array}{l}-0.0006 \\
(0.0060)\end{array}$ & $\begin{array}{c}0.0001 \\
(0.0061)\end{array}$ & $\begin{array}{c}0.0044 \\
(0.0055)\end{array}$ & $\begin{array}{c}0.0021 \\
(0.0058)\end{array}$ \\
\hline GROWTH & $\begin{array}{c}0.0469 \\
(0.0119)^{* * *}\end{array}$ & $\begin{array}{c}0.0482 \\
(0.0121)^{* * *}\end{array}$ & $\begin{array}{c}0.0518 \\
(0.0126)^{* * *}\end{array}$ & $\begin{array}{c}0.0502 \\
(0.0125)^{* * *}\end{array}$ \\
\hline RATE & $\begin{array}{c}0.0287 \\
(0.0064)^{* * *}\end{array}$ & $\begin{array}{c}0.0232 \\
(0.0058)^{* * *}\end{array}$ & $\begin{array}{c}0.0238 \\
(0.0075)^{* * *}\end{array}$ & $\begin{array}{c}0.0257 \\
(0.0058)^{* * *}\end{array}$ \\
\hline LNMSIZE & $\begin{array}{c}1.6689 \\
(0.2229)^{* * *}\end{array}$ & $\begin{array}{c}1.7239 \\
(0.2143)^{* * *}\end{array}$ & $\begin{array}{c}1.7781 \\
(0.2024)^{* * *}\end{array}$ & $\begin{array}{c}1.8333 \\
(0.2085)^{* * *}\end{array}$ \\
\hline LNPOPS & $\begin{array}{c}1.3827 \\
(0.7384)^{*}\end{array}$ & $\begin{array}{c}1.5203 \\
(0.7573)^{* *}\end{array}$ & $\begin{array}{c}1.3227 \\
(0.6916)^{*}\end{array}$ & $\begin{array}{c}0.9163 \\
(0.7464)\end{array}$ \\
\hline LAND & $\begin{array}{c}-0.0933 \\
(0.0527)^{*}\end{array}$ & $\begin{array}{c}-0.0961 \\
(0.0523)^{*}\end{array}$ & $\begin{array}{c}-0.0957 \\
(0.0576)^{*}\end{array}$ & $\begin{array}{c}-0.1218 \\
(0.0506)^{* *}\end{array}$ \\
\hline Constant & $\begin{array}{l}-42.6165 \\
(8.5735)\end{array}$ & $\begin{array}{l}-46.1321 \\
(8.9592)\end{array}$ & $\begin{array}{l}-44.4186 \\
(8.5389)\end{array}$ & $\begin{array}{l}-38.5696 \\
(9.1651)\end{array}$ \\
\hline Total Observation & 170 & 170 & 170 & 170 \\
\hline Total Party & 10 & 10 & 10 & 10 \\
\hline R-squared & 0.9544 & 0.9537 & 0.9489 & 0.9525 \\
\hline Adj. R-squared & 0.9497 & 0.9489 & 0.9436 & 0.9475 \\
\hline F-statistic & 200.3096 & 197.0387 & 177.7343 & 191.7951 \\
\hline Prob. (F-stat) & 0.0000 & 0.0000 & 0.0000 & 0.0000 \\
\hline
\end{tabular}

Note: (a) The value in parentheses is the standard error. (b) *.**.*** indicates the $10 \% .5 \%$ and $1 \%$ significance levels.

Based on the estimation results. it is also obtained information that the VOA variable does not affect FDI inflows. but the VOA variable has a positive direction as indicated by the positive coefficient value of the VOA variable. This may happen because not always countries that have a good democratic system also have good quality governance as well. On the other hand. not all countries with autocratic/centralistic systems have poor quality governance systems. this result is in line with the research of Daude \& Stein (2007) and Mengistu \& Adhikary (2011). The regression test results in table 3 show that the PSAB variable has no effect on FDI flows. which is indicated by a significant value that exceeds the $5 \%$ significance level. The insignificance of the relationship between political stability and FDI inflows indicates that stable political conditions have not been able to provide security guarantees for investors to invest in a country. The results of this study are different from 
those of Mengistu \& Adhikary (2011) but in line with the research of Daude \& Stein (2007). Meanwhile. the GOVE variable based on the estimation results in table 3 has a positive but insignificant relationship to FDI inflows. This result is in line with the research of Biro et al. (2019) with the possible reason why this indicator does not capture government conditions so that it is less relevant as a basis for investment decision making by investors.

Table 4 shows the estimation results of the GLS fixed effect regression cross-section weights for the V-VII model. In model V the governance variable that is included in the regulatory quality (RQ). model VI the governance variable that is entered is the rule of law (ROL). while model VII includes the control of corruption (COC) variable which is regressed together with the control variable.

Based on the results of data analysis. the RQ variable has a positive and significant effect on FDI inflows at the significance level $0=10 \%$. The results of this study are in line with research conducted by Daude \& Stein (2007) and Bannaga et al. (2013) who prove that the better the quality of laws and regulations produced by the government will have a significant impact on increasing FDI inflows to the host country. The existence of regulation is an important factor for the creation of economic growth. social welfare. and protection for the environment. However. sometimes the existence of regulation can also be a burden both economically and socially. Therefore. it is necessary to develop an efficient and lowcost regulatory system. The existence of a regulatory management system can help the government prepare better regulations and improve existing regulations. This is done to encourage sustainable economic development and investment.

Based on the regression estimation results in table 4. the ROL variable has a positive and significant effect on FDI inflows at the 5\% significance level. This result is not different from what was found by the research of Mengistu \& Adhikary (2011) and Gangi \& Abdulrazak (2012) which provide empirical evidence that the quality of law enforcement and good laws and regulations can be a driving factor for the influx of FDI. A good judicial system is considered capable of creating the trust and security that every investor seeks before deciding to invest in a country. If the government can create an effective legal system that protects both property rights and individual rights. it will attract more FDI flows. The regression estimation results of the COC variable and control variables on the dependent variable of FDI flow indicate that the COC variable has a positive and significant effect at the $5 \%$ significance level. The results of this estimate are in line with research by Mengistu \& Adhikary (2011) and Younsi \& Bechtini (2019) which prove that control of corruption is an important aspect of governance that affects FDI inflows. The results of this study indicate that high levels of corruption can be a barrier to increasing FDI inflows to host countries. 
Foreign investors generally avoid countries with high levels of corruption because corruption is seen as a bad thing. Besides. an economy with a culture of corruption is also considered to be able to cause inefficiency (Habib \& Zurawicki. 2002). Countries that can take decisive actions to eradicate corruption and implement more transparent policies will be able to attract more FDI.

Table 4. Estimation Results of Regression Models V-VII

\begin{tabular}{lccc}
\hline Independent & Model V & Model VI & Model VII \\
\cline { 2 - 4 } Variables & FGLS & FGLS & FGLS \\
\hline RQ & 0.2848 & & \\
ROL & $(0.1718)^{*}$ & & \\
COC & & 0.4147 & \\
& & $(0.2021)^{* *}$ & 0.4297 \\
DOMINV & & & $(0.1755)^{* *}$ \\
GROWTH & 0.0029 & 0.0004 & -0.0031 \\
& $(0.0057)$ & $(0.0058)$ & $(0.0061)$ \\
RATE & 0.0501 & 0.0480 & 0.0485 \\
& $(0.0120)^{* * *}$ & $(0.0118)^{* * *}$ & $(0.0121)^{* * *}$ \\
LNMSIZE & 0.0258 & 0.0239 & 0.0273 \\
& $(0.0063)^{* * *}$ & $(0.0058)^{* * *}$ & $(0.0056)^{* * *}$ \\
LNPOPS & 1.6127 & 1.6542 & 1.7495 \\
LAND & $(0.2412)^{* * *}$ & $(0.2180)^{* * *}$ & $(0.2100)^{* * *}$ \\
Constant & 1.5820 & 1.3750 & 1.5227 \\
Total Observation & $(0.7789)^{* *}$ & $(0.7021)^{*}$ & $(0.7529)^{* *}$ \\
Total Party & -0.0915 & -0.1120 & -0.1245 \\
R-squared & $(0.0523)^{*}$ & $(0.0514)^{* *}$ & $(0.0497)^{* *}$ \\
Adj. R-squared & -44.6590 & -41.7623 & -46.4212 \\
F-statistic & $(8.8441)$ & $(8.2916)$ & $(8.9207)$ \\
Prob. (F-stat) & 170 & 170 & 170 \\
\hline
\end{tabular}

Note: (a) The value in parentheses is the standard error. (b) *.**.*** indicates the $10 \% .5 \%$ and $1 \%$ significance levels

\section{Conclusion and Suggestion}

This study aims to analyze the effect of governance on the inflow of Foreign Direct Investment (FDI) in ASEAN countries from 2002-2018 with the GLS Cross-section weight fixed effect panel data regression. The estimation results show that the governance/governance variable in aggregate has a positive relationship with FDI inflows in ASEAN countries. This implies that the higher the value of the governance index. the more FDI inflows will be attracted. The quality of good governance is considered to be able to 
minimize transaction costs. increase long-term commitment from investors. and can be used as a basis for information for investors about how domestic market conditions include conditions of political stability. quality of policy formulation. and law enforcement systems that will ultimately stimulate MNEs. to invest more.

Also. this study provides empirical evidence that regulatory quality. rule of law. and control of corruption are important elements of governance that have a positive relationship to FDI inflows. The existence of regulations serves as a guideline for all stakeholders in carrying out all their activities. including in carrying out business activities or investing in a country. Besides. a good law enforcement system and the existence of a state commitment to eradicate corrupt practices are also considered capable of providing the trust and security that every investor is looking for. If the state can create a regulatory system. law enforcement. and a good corruption control system. it is possible to increase FDI inflows. especially for countries in the ASEAN region. In this study. there was no direct influence on the elements of voice and accountability. political stability. and absence of violence/terrorism and government effectiveness on FDI inflows. However. this does not rule out the possibility that these three variables still have an indirect effect on FDI inflows.

Considering the importance of FDI as a source of external finance that can stimulate economic development in most countries. the success of FDI in driving economic development is very much dependent on the quality of absorption of FDI itself. Therefore. policymakers or authorities who have the authority need to take firm and proactive action to make the elements of good governance a solid basis to provide assurance and security for domestic and foreign investors. Improvements are needed in all aspects of governance to create a conducive investment climate to increase FDI inflows to a country. including Indonesia. The government needs to pay attention to the quality of the resulting laws and regulations. the quality of law enforcement. and decisive action to eradicate corruption to attract more FDI.

The results of this study have added to the latest information regarding the importance of aspects of governance as one of the factors that attract the entry of FDI into a country. including countries in the ASEAN region. Considering that the scope of this research only examines one area. therefore this research also provides some input for the development of future research such as using a governance approach with different indicators. using different analytical methods. or expanding the coverage of countries and periods. used and can also include the effects of the Covid-19 pandemic as a variable in further research. 


\section{REFERENCE}

ASEAN Community Statistical System (2020). Flows of Inward Foreign Direct Investment (FDI) to ASEAN Countries.

Alam. Abdullah; Shah. S. Z. A. (2013). Determinants of foreign direct investment in OECD member countries. Journal of Economic Studies. 40(4). 515-527. https://doi.org/10.1108/JES-10-2011-0132

Asiedu. E. (2002). On the Determinants of Foreign Direct Investment to Developing Countries : Is Africa Different? World Development. 30(1). 107-119.

Bannaga. A.. Gangi. Y.. Abdrazak. R.. \& Al-fakhry. B. (2013). The effects of good governance on foreign direct investment inflows in Arab countries. Applied Financial Economics. 23(15). 1239-1247. https://doi.org/10.1080/09603107.2013.802088

Bellos. S.. \& Subasat. T. (2012). Governance and foreign direct investment : a panel gravity model approach. International Review of Applied Economics.

Biro. F. P.. Erdey. L.. Gall. J.. \& Markus. A. (2019). The effect of governance on foreign direct investment in Latin America - issues of model selection. Global Economy Journal. 19(1). https://doi.org/10.1142/S2194565919500064

Bissoon. O. (2012). Can Better Institutions Attract More Foreign Direct Investment (FDI)? Evidence from Developing Countries. Journal of European Economy. 11.

Blaise. S. (2005). On the link between Japanese ODA and FDI in China : a microeconomic evaluation using conditional logit analysis. Applied Economics. 37(1). 51-55. https://doi.org/10.1080/0003684042000281534

Borensztein. E.. Gregorio. J. De. \& Lee. J. (1998). How does foreign direct investment affect economic. Journal of International Economics. 45. 115-135.

Buchanan. B. G.. Le. Q. V. \& Rishi. M. (2012). International Review of Financial Analysis Foreign direct investment and institutional quality: Some empirical evidence. International Review of Financial Analysis. 21(24). 81-89. https://doi.org/10.1016/j.irfa.2011.10.001

Cambazoglu. B.. \& Karaalp. H. S. (2014). Does foreign direct investment affect economic growth? The case of Turkey. International Journal of Social Economics. 41(6). 434449. https://doi.org/10.1108/IJSE-02-2012-0173

Cuervo-cazurra. A. (2008). Better the devil you don't know : Types of corruption and FDI in transition economies. 14. 12-27. https://doi.org/10.1016/j.intman.2007.02.003

Daude. D.. \& Stein. E. (2007). The Quality of Institutions and Foreign Direct Investment. Economics \& Politics. 19(3). 317-344. https://doi.org/10.1111/j.1468- 
0343.2007.00318.x

Ekananda. M. (2016). Analisis Ekonometrika Data Panel (Edisi 2). Jakarta: Mitra Wacana Media.

Gangi. Y. A.. \& Abdulrazak. R. S. (2012). The impact of governance on FDI flows to African countries. World Journal of Entrepreneurship. Management and Sustainable Development. 8(2/3). 162-169. https://doi.org/10.1108/20425961211247761

Globerman. S.. \& Sapiro. D. (2002). Global Foreign Direct Investment Flows : The Role of Governance Infrastructure. World Development. 30(11). 1899-1919.

Habib. M.. \& Zurawicki. L. (2002). Corruption and foreign direct investment. Journal of International Business Studies. 33(2). 291-307.

Iamsiraroj. S. (2016). The foreign direct investment - economic growth nexus. International Review of Economics and Finance. 42. 116-133. https://doi.org/10.1016/j.iref.2015.10.044

Jensen. N. M. (2003). Democratic Governance and Multinational Corporations : Political Regimes and Inflows of Foreign Direct Investment. International Organization. 57. 587-616. https://doi.org/10.1017/SO020818303573040

Kahouli. B.. \& Maktouf. S. (2015). The determinants of FDI and the impact of the economic crisis on the implementation of RTAs : A static and dynamic gravity model. International Business Review. 24(3). 518-529. https://doi.org/10.1016/j.ibusrev.2014.10.009

Kaufmann. D.. Kraay. A.. \& Mastruzzi. M. (2011). The Worldwide Governance Indicators: Methodology and Analytical Issues. Hague Journal on the Rule of Law. 3(02). 220-246. https://doi.org/10.1017/S1876404511200046

Kayalvizhi. P. N.. \& Thenmozhi. M. (2017). AC NU. Emerging Markets Review. https://doi.org/10.1016/j.ememar.2017.11.007

Kayalvizhi. P. N.. \& Thenmozhi. M. (2018). Does quality of innovation . culture and governance drive FDI ?: Evidence from emerging markets $\square$. Emerging Markets Review. 34. 175-191. https://doi.org/10.1016/j.ememar.2017.11.007

Mengistu. A. A.. \& Adhikary. B. K. (2011). Does good governance matter for FDI inflows? Evidence from Asian economies. Asia Pacific Business Review. 17(3). 281-299. https://doi.org/10.1080/13602381003755765

Sahoo. P.. Nataraj. G.. \& Dash. R. K. (2014). Foreign Direct Investment in South Asia Policy. Impact. Determinants and Challenges. New Delhi: Springer India.

Ullah. I.. \& Khan. M. A. (2017). Institutional quality and foreign direct investment inflows : the evidence from Asian countries. Journal of Economic Studies. 
https://doi.org/ttps://doi.org/10.1108/JES-10-2016-0215

UNCTAD. (2003). Foreign Direct Investment and Performance Requirements: New Evidence from Selected Countries. New York and Geneva. Retrieved from https://unctad.org/en/Docs/iteiia20037_en.pdf

UNCTAD. (2014). World Investment Prospects Survey 2014-2016.

Voyer. P. A.. \& Beamish. P. W. (2004). The Effect of Corruption on Japanese Foreign Direct Investment. 211-224.

World Economic Forum. (2015). The Global Competitiveness Report 2015-2016.

Xaypanya. P.. Rangkakulnuwat. P.. \& Paweenawat. S. W. (2015). The determinants of foreign direct investment in ASEAN: The first differencing panel data analysis. International Journal of Social Economics. 42(3). 239-250. https://doi.org/10.1108/IJSE-10-20130238

Younsi. M.. \& Bechtini. M. (2019). Does good governance matter for FDI ? New evidence from emerging countries using a static and dynamic panel gravity model approach. Economic of Transition and Institutional Change. 27. 841-860. https://doi.org/10.1111/ecot.12224 